\title{
Bacterial Abundance and Dehydrogenase Activity in Selected Agricultural Soils from Lublin Region
}

\author{
Agnieszka Wolińska ${ }^{1 *}$, Hanna Rekosz-Burlaga ${ }^{2}$, Agata Goryluk-Salmonowicz $^{2}$, \\ Mieczysław Błaszczyk ${ }^{2}$, Zofia Stępniewska ${ }^{1}$
}

\author{
${ }^{1}$ Department of Biochemistry and Environmental Chemistry, Institute of Biotechnology, \\ The John Paul II Catholic University of Lublin, Konstantynów 1 I, 20-708 Lublin, Poland \\ ${ }^{2}$ Department of Microbial Biology, Warsaw University of Life Sciences, \\ Nowoursynowska 159, 02-776 Warsaw, Poland
}

Received: March 5, 2015

Accepted: September 7, 2015

\begin{abstract}
The aim of our study was to analyze the impact of soil agriculture management on bacterial abundance (expressed as total microorganism count plus copiotrophic and oligotrophic bacteria numbers) and soil dehydrogenase activity. Four different soil units agriculturally exploited (under oat-type crops) and the same number of control soils not agriculturally used were taken for study in April 2014 from the surface layer $(0-20 \mathrm{~cm})$. Under laboratory conditions the soils were subjected to analysis of: $\mathrm{pH}$, total carbon, total microbial counts, copiotrophic and oligotrophic bacteria numbers, and dehydrogenase activity. The first consequences of agricultural practices were a decrease of $\mathrm{pH}$ toward acidic conditions and impoverishment of total carbon. Secondly, it was demonstrated that agricultural soil usage in relation to control sites affected biological properties by decreasing total microbial counts (by 20-75\%), copio- and oligotrophic bacteria abundance (by $15-$ $33 \%$ ), and dehydrogenase activity (by 25-71). The ratio of oligotrophic to copiotrophic bacteria (O:C), being an indicator of soil biological balance, ranged $0.81-1.53$ and 1.02-2.40 for arable and control soils, respectively. Lower values of biological factors observed in agricultural soils clearly indicated a progressive reduction of bacterial abundances and metabolic activities.
\end{abstract}

Keywords: agricultural soils, microorganism number, dehydrogenase activity, $\mathrm{pH}$

\section{Introduction}

The effects of different management practices on soil properties may provide essential information for assessing environmental impact [1]. Generally, agricultural soils are more vulnerable to soil erosion and loss of organic matter [1]. Agrotechnical treatment associated with soil cultivation constitutes an important element through which agriculture can influence the soil environment [2]. Soil microbiological activity is one of the most essential soil biological elements

*e-mail: awolin@kul.pl decisive with respect to its functioning, but also acting as an important indicator of its fertility $[2,3]$.

Torsvik et al. [4] and Tscharntke et al. [5] indicated that agricultural types of soil contain much smaller numbers of microorganisms (about 140-150 species per g), in comparison with natural soils (thousand of species per g), whereas soil biodiversity degradation has been estimated to affect $16-40 \%$ of terrestrial area [6]. It should also be mentioned that agricultural soils may not contain stable microbial communities, but have greater abundance of groups living according to strategy $r$ (copiotrophs) and adapting to maximizing their intrinsic rate of growth when resources 
Table 1. Locations of agricultural soils with crop type and description of control sites (Lublin region).

\begin{tabular}{|c|c|c|c|c|c|}
\hline Soil type (FAO) & Crop type (1991) & Crop type (2014) & Village & Coordinates & Control sites \\
\hline Orthic Podzol & Potatoes & Oat & Dęba & $\begin{array}{c}22^{\circ} 10^{\prime} 17.7 ” \\
51^{\circ} 26^{\prime} 24.6^{\prime \prime}\end{array}$ & $\begin{array}{c}30 \text {-year-old meadow } \\
\text { planted with fruit trees }\end{array}$ \\
\hline Eutric Cambisol & Potatoes & Oat & Lany & $\begin{array}{c}22^{\circ} 15^{\prime} 19.0^{\prime \prime} \\
51^{\circ} 23^{\prime} 0.9^{\prime \prime}\end{array}$ & 20 -year-old field woodlots \\
\hline Eutric Histosol & Oat & Oat & Wólka Kątna & $\begin{array}{c}22^{\circ} 16^{\prime} 38.9^{\prime \prime} \\
51^{\circ} 25^{\prime} 27.3\end{array}$ & $\begin{array}{c}20 \text {-year-old meadow } \\
\text { (mowed once a year) }\end{array}$ \\
\hline Rendzina Leptosol & Oat & Oat & Brzeziny & $\begin{array}{c}23^{\circ} 11^{\prime} 43.9^{\prime \prime} \\
51^{\circ} 12^{\prime} 10.8^{\prime \prime}\end{array}$ & $\begin{array}{c}30 \text {-year-old meadow } \\
\text { (mowed once a year) }\end{array}$ \\
\hline
\end{tabular}

are abundant [7]. Copiotrophs preferentially consume labile soil organic $\mathrm{C}$ pools and have high nutritional requirements, so their metabolic activity is quickly reduced and consequently their number in the soil decreases $[8,9]$. In contrast, oligotrophs (strategy $K$ ) exhibit slower growth rates and are likely to outcompete copiotrophs under low nutrient availability due to their higher substrate affinities [10]. Thus, soils with large amounts of available organic C seem to favour copiotrophs while oligotrophs tend to predominate in soils where organic $\mathrm{C}$ quality and/or quantity is low $[8,11]$. Consequently, not only the $\mathrm{O}: \mathrm{C}$ ratio provides a proxy for soil-nutrient supply but also predominantly about the microbial community degradation as a consequence of agricultural practices. The lack of biodiversity is another reason for agricultural soils not being able to become naturally regenerated, which may lead to their inability to regain the satisfactory level of fertility $[3,9]$. Therefore, determination of total microorganism abundance and - especially in agricultural soils - concentrations on oligo- and copiotroph numbers as sensitive factors of biological degradation state should be strongly recommended.

Other biological indicators that have been widely studied are enzymes, particularly dehydrogenases, which are present in all living microbial cells and which can be used as a general measure of total microbial activity $[12,13]$. Soil enzymatic activity assays act as potential indicators of ecosystem quality being operationally practical, sensitive, integrative, described as "biological fingerprints" of past soil management, and relate to soil tillage and structure $[14,15]$.

In the presented study our hypotheses were as follows:

a) soil biological properties are different in the area under cultivation than in natural soils (non-cultivated),

b) long-term agricultural management practices are the reason behind the reduction of bacterial abundance and reduction of metabolic activities in arable soils.

Consequently, the objective of our work was to demonstrate the effect of soil agricultural usage on selected biological properties, like: total microbial counts (TMC), the abundance of copio- and oligotrophic bacteria, dehydrogenase activity (DHA), and finally to determine correlations between mentioned parameters. It should also be emphasised that this aim is consistent with Biodiversity Strategy 2011-2020 and European Project ENVASSO, strongly pro- moting the protection strategy of the microbial community - especially in arable soil with a description of soil microbiological degradation state.

\section{Materials and Methods}

The study was conducted as part of a long-term experiment (started in 1991) connected with the organization of the database of Polish arable mineral soil that was created by the Institute of Agrophysics, Polish Academy of Sciences in Lublin [16, 17]. In April 2014 we returned to select soil locations in the Lublin region (Table 1) to take samples for biological analysis. Extractions of soils were performed using Egner's bow from topsoil layer $(0-20 \mathrm{~cm})$ agriculturally exploited (three replicates of $2 \mathrm{~kg}$, consisting of about 50 samples taken from a $100 \mathrm{~m}^{2}$ area). Arable soils were collected from non-ploughed places in order to avoid artifacts from plugging perturbations [9]. Also, control samples were taken from non-agriculturally cultivated and nonforested sites (covered at least one hectare in area), located in close proximity to basic soils and belonging to the same soil type (Table 1). For this study four different types of soil were taken: Orthic Podzol, Eutric Cambisol, Eutric Histosol, and Rendzina Leptosols. Under laboratory conditions each soil sample was passed through a 2.0-mm sieve to remove pieces of rocks and plant material, and stored at $4^{\circ} \mathrm{C}$ prior to further analysis.

$\mathrm{pH}$ was determined from a 2:1 soil suspension in distilled water using a multifunctional pIONneer 65 potential meter (Radiometer Analytical S.A., France) equipped with a glass electrode (Cartrode pH E16M340). The measurements were taken in triplicate after stabilizing the readings.

Total carbon (TC) was appointed using an automatic carbon analyzer TOC-VCSH SSM 5000A (Shimadzu, Japan). Soil samples (150 mg) were pulverized, dried prior to analysis, and then combusted at $900^{\circ} \mathrm{C}$ in a column containing platinum and cobalt oxide catalyst [9]. Under these conditions all carbon compounds were converted into carbon dioxide form, and detected by an infrared detector (NDIR). Each TC recording was realized in triplicate.

TMC were determined by fluorescence microscopy techniques using a nucleic acid binding fluorescent dye (4' 6-diamidino-2-phenylindole DAPI, Sigma). Each soil sample $(1 \mathrm{~g})$ was placed in $1 \mathrm{ml}$ of potassium-phosphate- 
buffered saline (1M KPBS pH 7.4). To separate microorganisms from soil particles the ultrasonic treatment in sonifying ice-water baths was performed ( 3 times $\times 1$ min., $2 \mathrm{~W}$ ). After sonication samples were spun (1 min., 3,000 rpm), the supernatant was used to prepare microscopic slides. Depending on bacterial density the supernatant was diluted 10 or 100 times. Final stain concentration of DAPI was $2.5 \mu \mathrm{g} / \mathrm{ml}$ and time of staining was 15 minutes [18]. The slides were viewed using an epifluorescence microscope Axio Imager M2 Research Microscope (ZEISS) equipped with filters of 360-370 nm excitation and $400 \mathrm{~nm}$ emission. To obtain the precision of count, 400 cells per slide were counted. TMC were counted using the following equation [19]:

$$
\text { Bacteria } \mathrm{g}^{-1}=N \times A / V
$$

...where $N$ is total number of bacteria counted/number of micrometer fields counted, $A$ is area of cover slip/area of micrometer field, and $V$ is volume of sample placed on microscope slide.

The number of oligotrophic and copiotrophic bacteria was determined by a plate method, according to Koch procedure on adequate agar substrates. The mean number of colonies was converted into soil dry mater on the basis of the amount and moisture of the soil samples [1]. The oligotrophic bacteria number expressed as colony forming units (cfu $\cdot \mathrm{g}^{-1} \mathrm{~d}$.m. soil) were counted on 1,000-fold diluted nutritive broth (BTL) at $28^{\circ} \mathrm{C}$ after 21 incubation days [20]. The copiotrophic bacteria number ( $\mathrm{cfu} \cdot \mathrm{g}^{-1} \mathrm{~d} . \mathrm{m}$. soil) was determined on nutritive broth (BTL) at $28^{\circ} \mathrm{C}$ after seven incubation days [20].

Soil DHA was estimated by reducing 2.3.5-triphenyltetrazolium chloride (TTC), according to the procedure of Casida et al. [21]. Soil samples (6 g) were mixed with $120 \mathrm{mg} \mathrm{CaCO}, 1 \mathrm{ml} \mathrm{1 \%}$ (w/v) TTC, $4 \mathrm{ml}$ of distilled water and incubated for $20 \mathrm{~h}$ at $30 \pm 1^{\circ} \mathrm{C}$ (Heraens Instruments). Enzymatic activity was quantified by reference to a calibration curve constructed with data obtained by incubating TTC standards under the same conditions described above, and was expressed in $\mu \mathrm{gTPF} \cdot \mathrm{g}^{-1} \cdot \mathrm{min}^{-2}[13]$.

Data reported as mean \pm standard error (SE) of the mean were examined using standard variance analysis (ANOVA). Mean separations were made for significant effect with Tukey's test at the probability $\mathrm{p}<0.05$. Pearson's correlation coefficient between chemical and biological properties was calculated. Statistical computations were realized using the STATISTICA 9.0 statistical software package (StatSoft, Inc. USA).

\section{Results and Discussion}

The relevant chemical characteristics of the agricultural and control soils, with determined $\mathrm{O}: \mathrm{C}$ ratio, are reported in Table 2. It was observed that systematical agricultural practices significantly modify soil $\mathrm{pH}$ and $\mathrm{TC}$ content. Agricultural soils were characterized by acidic $\mathrm{pH}$ ranged 4.85-5.58, whereas TC amounted to $0.98-2.69 \%$. Control
Table 2. Values of $\mathrm{pH}, \mathrm{TC}$, and $\mathrm{O}: \mathrm{C}$ ratio in agricultural and control soils.

\begin{tabular}{|l|l|c|c|c|}
\hline $\begin{array}{c}\text { Soil type } \\
(\text { FAO) }\end{array}$ & $\begin{array}{c}\text { Land } \\
\text { management }\end{array}$ & $\mathrm{pH}\left(\mathrm{H}_{2} \mathrm{O}\right)$ & $\mathrm{TC}(\%)$ & $\mathrm{O}: \mathrm{C}$ \\
\hline \multirow{2}{*}{$\begin{array}{l}\text { Orthic } \\
\text { Podzol }\end{array}$} & Agricultural & $5.23 \pm 0.06^{\mathrm{a}}$ & $0.98 \pm 0.002^{\mathrm{a}}$ & 1.40 \\
\cline { 2 - 5 } & Control & $6.27 \pm 0.005^{\mathrm{b}}$ & $1.76 \pm 0.12^{\mathrm{b}}$ & 2.40 \\
\hline $\begin{array}{l}\text { Eutric } \\
\text { Cambisol }\end{array}$ & Agricultural & $5.45 \pm 0.03^{\mathrm{a}}$ & $2.69 \pm 0.04^{\mathrm{a}}$ & 0.81 \\
\cline { 2 - 5 } & Control & $5.79 \pm 0.04^{\mathrm{b}}$ & $2.06 \pm 0.19^{\mathrm{b}}$ & 1.02 \\
\hline $\begin{array}{l}\text { Eutric } \\
\text { Histosol }\end{array}$ & Agricultural & $4.85 \pm 0.03^{\mathrm{a}}$ & $1.01 \pm 0.19^{\mathrm{a}}$ & 1.53 \\
\cline { 2 - 5 } & Control & $5.27 \pm 0.005^{\mathrm{b}}$ & $3.63 \pm 0.14^{\mathrm{b}}$ & 1.71 \\
\hline $\begin{array}{l}\text { Rendzina } \\
\text { Leptosol }\end{array}$ & Agricultural & $5.58 \pm 0.11^{\mathrm{a}}$ & $1.25 \pm 0.05^{\mathrm{a}}$ & 1.27 \\
\cline { 2 - 5 } & Control & $7.39 \pm 0.02^{\mathrm{b}}$ & $4.35 \pm 0.43^{\mathrm{b}}$ & 1.50 \\
\hline
\end{tabular}

Means followed by the same letter do not differ significantly according to the Tukey test $(\mathrm{p}<0.05)$.

(non-cultivated) soils had higher $\mathrm{pH}$ (5.27-7.39) and were richer in TC (1.76-4.35\%). These results are comparable with other results, indicating a decreasing trend both for $\mathrm{pH}$ and TC in arable soils $[1,2,9,15]$, which confirmed reduction of bacterial abundance and reduction of biological processes in agricultural soils and is consistent with the applied hypothesis. It should also be emphasized that soil acidification modifies the population number of soil microorganisms and nutrient availability $[2,9]$.

Total microbial count depending on soil management practices are presented in Fig. 1. Regardless of soil type, lower microorganism numbers were noted in agriculturally exploited soils than in control sites. Differences in TMC between arable and control soils in every case had significant character $(\mathrm{p}<0.05)$, which also verified our hypothesis. Among investigated agricultural soil the highest TMC were noted in Eutric Histosol $\left(3.5 \times 10^{9} \mathrm{cfu} \cdot \mathrm{g}^{-1}\right)$, while the lowest abundance in Orthic Podzol was estimated $\left(1.7 \times 10^{9} \mathrm{cfu} \cdot \mathrm{g}^{-1}\right)$. Two remaining arable soils characterized similar TMC levels, amounting to $2.6-2.8 \times 10^{9} \mathrm{cfu} \cdot \mathrm{g}^{-1}$ for Eutric Cambisol and Rendzina Leptosol. TMC noted in control soils were by $25-82 \%$ higher than in agricultural sites. The analogical

\section{Total microbial counts}

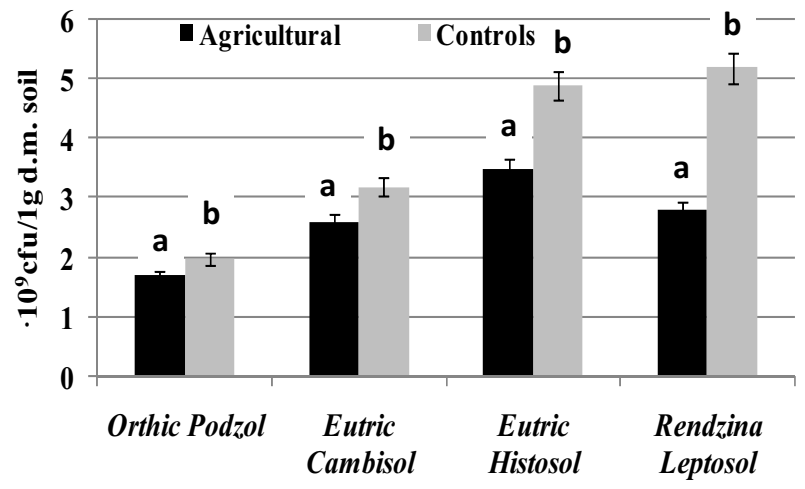

Fig. 1. Total microorganism counts $\left(10^{9}\right.$ c.f.u./g d.m. soil $)$ in agricultural and control soils. Means followed by the same letter do not differ significantly according to the Tukey test $(\mathrm{p}<0.05)$. 
trend for microorganism abundance in soil under the notillage system was indicated by Swędrzyńska et al. [1, 2]. Also, Janušauskaite et al. [21] noted that uncultivated soils had higher (by 25.5\%) microbial abundance than arable soils.

Interesting conclusions were drawn on the basis of the analysis of soil bacteria divided into the copiotroph and oligotrophy groups [2], which is demonstrated in Fig. 2. Primarily, oligotrophic bacteria dominated in the investigated soil types, both cultivated as controls, with one exception in regards to Eutric Camisole, when a higher abundance of copiotrophs vs. oligotrophs was noted. This might be explained by the fact that agriculturally exploited Eutric Cambisol contained the highest amount of TC (2.69\%) among all investigated soils (Table 2). Copiotrophs are the type of bacteria whose development is preconditioned by appropriate, easily available carbon content, which is intensively mineralized by them $[1,2,11,22]$. In the current study its number ranged from 64 to $246 \times 10^{4}$ $\mathrm{cfu} \cdot \mathrm{g}^{-1}$ for cultivated Orthic Podzol and Eutric Cambisol, respectively. In the case of arable Eutric Histosol and Rendzina Leptosol, the abundance of copiotrophs was estimated as $100-193 \times 10^{4} \mathrm{cfu} \cdot \mathrm{g}^{-1}$. A decidedly higher copiotroph number was noted in control soils and amounted to $59-271 \times 10^{4} \mathrm{cfu} \cdot \mathrm{g}^{-1}$. Our data are compatible with results of Swędrzyńska et al. [1, 2], who noted a lower copiotroph count in systematically cultivated and tillage soils. Oligotrophic bacteria reached a higher level of abundance $\left(89.5-246.2 \times 10^{4} \mathrm{cfu}^{-1} \mathrm{~g}^{-1}\right)$ in cultivated and control (142.7$\left.320 \times 10^{4} \mathrm{cfu}^{-\mathrm{g}^{-1}}\right)$ soils. Generally its domination was by 40 $60 \%$ higher in cultivated and control soils, respectively, vs. copiotrophs. Among investigated soil types the highest oligotrophic bacteria number was noted in Rendzina Leptosol, both cultivated and controls, whereas the lowest was in Orthic Podzol. Domination of oligotrophic over copiotrophic bacteria numbers due to economic processing of the energy substrate by oligotrophs is of significant importance from the point of view of maintenance of organic matter in soil $[1,11,22]$. It should also be emphasized that the oligotrophic bacteria group processes organic matter economically and shows a negative response to excessively elevated concentrations of carbon compounds in the soil environment $[1,8,11]$. However, this does not

\section{Oligotrophic bacteria number}

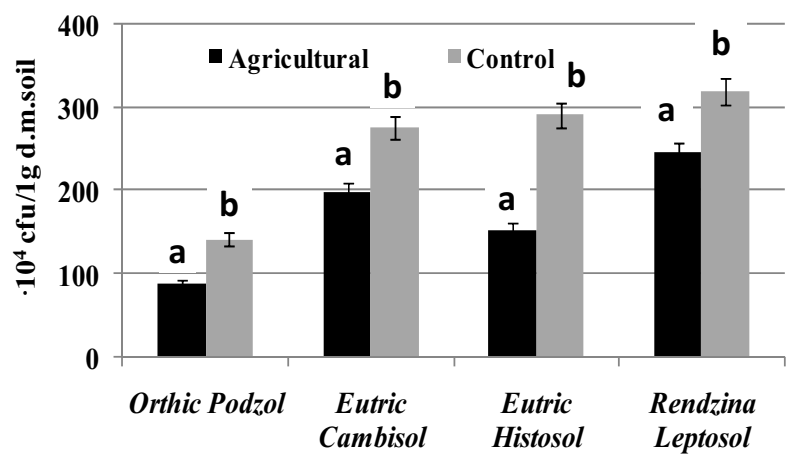

mean that their high proportions in soil suggest its poor fertility $[2,23]$.

Wolna-Maruwka et al. [24] indicated that soil biological equilibrium depends on the ratio of oligotrophic to copiotrophic microorganisms. Their quantitative relationship, referred to as $\mathrm{O}: \mathrm{C}$, provides one of the indicators of the direction of microbiological changes of organic matter [25]. Consequently, the applied agricultural practices may seriously disturb soil biological equilibrium [24]. Determined $\mathrm{O}: \mathrm{C}$ ratios are shown in Table 2. We found that proportions of oligotrophs $v s$. copiotrophs strongly depended on the method of land use, as a significantly lower O:C ratio characterized cultivated soils rather than controls. The value of $\mathrm{O}: \mathrm{C}$ coefficient changed from 0.81 to 1.53 in agricultural and from 1.02 to 2.40 in control soils. Lower levels of O:C testified about stronger soil biological degradation and soil tiredness. Based on the $\mathrm{O}: \mathrm{C}$ ratio, among soils investigated in the current study agriculturally exploited Eutric Cambisol seemed to be the most degraded (O:C 0.81), whereas the least susceptible to biological degradation proved to be Eutric Histosol. Swędrzyńska and Grześ [2] noted $\mathrm{O}: \mathrm{C}$ ratios in control and cultivated grey-brown podzolic soils as 2.12 and 1.82, which is comparable with our results, particularly in relation to control sites and quite higher than what we calculated in cultivated soils. This might suggest that agricultural soils from the Lublin region are probably more biologically degraded than those of the Poznan District as investigated by mentioned authors [2].

Soil enzymatic activity finds its reflection in the metabolic activity of whole microorganisms [2, 12]. Since dehydrogenases are exclusively of microbiological origin, their activity is recommended as a sensitive indicator of numbers and activity of living microorganisms [2, 9, 13]. DHA seemed to be a strongly variable factor depending on land use (Fig. 3). Significantly lower values of DHA in cultivated soils were noted, while they reached much higher levels in control soils. This also indicated the validity of our hypothesis about reduction of biological processes in agricultural soils. Analogically to microorganism abundance, DHA achieved minimal values in Orthic Podzol (agriculturally exploited), and maximal in Eutric Histosol. Values of DHA noted in control soils were found to be $25-137 \%$ higher than in cultivated soils. Reduction of DHA in culti-

Fig. 2. The number of oligotrophic and copiotrophic bacteria $\left(10^{4}\right.$ c.f.u./g d.m. soil) in agricultural and control soils. Means followed by the same letter do not differ significantly according to the Tukey test $(\mathrm{p}<0.05)$.

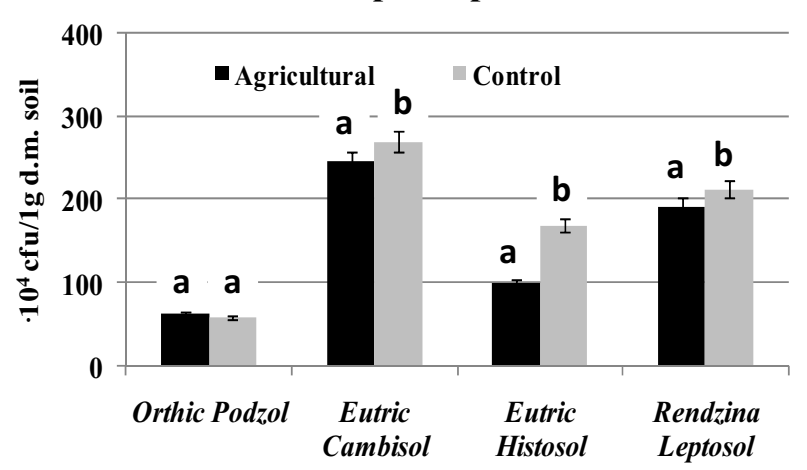


Table 3. Correlations among soil DHA, microorganism abundance, and chemical factors ( $\mathrm{pH}, \mathrm{TC}) ; \mathrm{n}=24$.

\begin{tabular}{|c|c|c|c|c|c|c|}
\hline Factor & $\mathrm{pH}$ & $\mathrm{TC}^{\mathrm{a}}$ & DHA $^{\mathrm{b}}$ & Oligo $^{\mathrm{c}}$ & Copio $^{\mathrm{c}}$ & $\mathrm{TMC}^{\mathrm{d}}$ \\
\hline $\mathrm{pH}$ & & 0.466 n.s. & $-0.858^{* *}$ & $0.558^{*}$ & $0.646^{*}$ & $0.481^{*}$ \\
\hline $\mathrm{TC}^{\mathrm{a}}$ & & & $0.998^{* * *}$ & $0.648^{* *}$ & $0.953^{* * *}$ & $0.526^{*}$ \\
\hline DHA $^{\mathrm{b}}$ & & & & $0.966^{* * *}$ & $0.519^{*}$ & $0.928^{* * *}$ \\
\hline Oligo $^{\mathrm{c}}$ & & & & & $0.776^{*}$ & $0.471^{*}$ \\
\hline Copio $^{\mathrm{c}}$ & & & & & & $0.396^{*}$ \\
\hline
\end{tabular}

${ }^{\mathrm{a}}-(\%),{ }^{\mathrm{b}}-\left(\mu \mathrm{gTPF} \cdot \mathrm{g}^{-1} \cdot \mathrm{min}^{-2}\right),{ }^{\mathrm{c}}-\left(\mathrm{cfu} \cdot 10^{4} / 1 \mathrm{~g} \mathrm{~d}\right.$.m. soil $),{ }^{\mathrm{d}}-\left(\mathrm{cfu} \cdot 10^{\%} / 1 \mathrm{~g} \mathrm{~d} . \mathrm{m}\right.$. soil $)$

$*, * *, * * *$ - indicate significance at the 5,1 , and $0.1 \%$ levels, respectively,

n.s. - no significant differences

vated soils was also observed by other researchers $[1,2$, 13]. Additionally, Janušauskaite et al. [21] reported an increase of DHA by $5.6 \%$ in non-cultivated Cambisols.

Statistical relationships between all investigated factors are presented in Table 3. In most cases positive correlations were found with one exception (DHA-pH) when a negative relationship was confirmed $\left(-0.858^{* * *}\right)$. However, this is in general agreement with the findings of previous studies [13, 26, 27] describing similar negative relationships. Dehydrogenases are $\mathrm{pH}$ dependent and its activity tends to increase with soil pH [28]. Brzezińska et al. [26] and Włodarczyk [27] reported that the best $\mathrm{pH}$ conditions for DHA ranged 6.6-7.2. Agricultural soils investigated in the current study were characterized by acidic $\mathrm{pH}(4.85-5.58)$, which makes unfavorable conditions for DHA and thus lower values of enzymatic activity were recorded. Highly significant positive correlations were noted between soil biological parameters: TMC, copio- and oligotrophic bacteria numbers, and DHA. This confirms a very high participation of microorganisms in soil total biological activity $[2,29]$. Noteworthy is strong correlations between DHA and TMC $\left(0.928^{* * *}\right)$, testifying to the close connection between intracellular dehydrogenases and total microorganism abundance. Among investigated environmental variables a stronger effect on biological parameters caused TC as evidenced by higher values of rho Pearson's correlation coefficient (Table 3), which remained in agreement with observations of Classens et al. [30]. The effect of soil

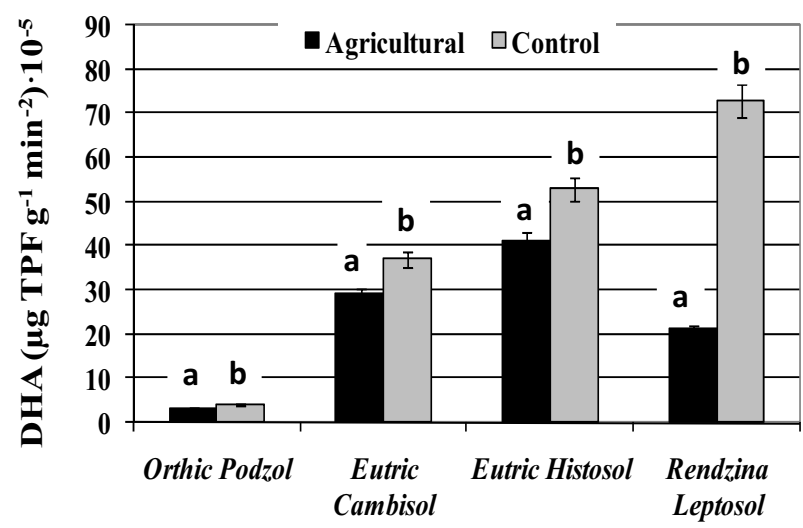

Fig. 3. Dehydrogenase activity $\left(\mu \mathrm{gTPF} \cdot \mathrm{g}^{-1} \cdot \mathrm{min}^{-2}\right) \cdot 10^{-5}$ in agricultural and control soils. Means followed by the same letter do not differ significantly according to the Tukey test $(\mathrm{p}<0.05)$.
$\mathrm{pH}$ was also significant, but with respect to the presented results, determined values of r-coefficient were lower in relation to TC. Swędrzyńska et al. [1, 2] noted highly significant $\left(\mathrm{r}=0.877^{* *}\right.$ and $\left.\mathrm{r}=0.805^{* *}\right)$ positive correlations between numbers of oligotrophic and copiotrophic bacteria and indicated that this deserves attention. In the current study we also noted a similar relationship $\left(\mathrm{r}=0.776^{*}\right)$, confirming suggestions of Swędrzyńska et al. [1, 2].

\section{Conclusions}

Our study revealed that soil agricultural treatments contribute to a significant decrease of $\mathrm{pH}$ and depletion of TC $(\mathrm{p}<0.05)$. The lower $\mathrm{pH}$ and $\mathrm{TC}$ values in agricultural soils resulted in a decrease of TMC (even by $75 \%$ ), and copioand oligotrophic bacteria numbers (by 15-33\%) in relation to control (non-cultivated) soils.

Agriculturally exploited soils were dominated by oligotrophic bacteria populations; their abundance was approximately $30-53 \%$ higher than copiotrophic bacteria numbers. A similar trend was noted in relation to DHA and it was c.a. by $25 \%$ lower in arable Orthic Podzol, Eutric Camisole, and Eutric Histosol than in control soils. However, the largest variations in enzymatic activity were found in regards to Rendzina Leptosol, wherein as a consequence of agricultural soil usage DHA was reduced by $71 \%$ compared to non-agricultural exploited (control) soil.

The biological equilibrium ratio $(\mathrm{O}: \mathrm{C})$ achieved lower values $(0.81-1.53)$ in agricultural soils, but higher values (1.02-2.40) in controls, indicating a clearly progressive biological degradation of farmland. Among examined agricultural soil samples the most biologically degraded proved to be Eutric Cambisol ( $\mathrm{O}: \mathrm{C}=0.81$ ), while the least susceptible to degradation was Eutric Histosol ( $\mathrm{O}: \mathrm{C}=1.53$ ). In summary, our study confirmed assumptions of wagered hypotheses that soils with systematically, intensive agricultural exploitation are biologically degraded.

\section{Acknowledgements}

This project was financed by the National Science Centre (Poland), granted on the basis of decision DEC2013/09/D/NZ9/02482. The authors are also grateful for 
our technical assistant Andrzej Górski for his participation on the field trips and Marek Pazur from the Institute of Agrophysics Polish Academy of Sciences in Lublin for his help in precisely locating places for soil sampling (strictly according bank soil sample points).

\section{References}

1. SWĘDRZYŃSKA D., MAŁECKA I., BLECHARCZYK A., SWĘDRZYŃSKI A., STARZYK J. Effects of various long-term tillage systems on some chemical and biological properties of soil. Pol. J. Environ. Stud. 22, (6), 1835, 2013.

2. SWĘDRZYŃSKA D., GRZEŚ S. Microbiological parameters of soil under sugar beet as a response to the long-term application of different tillage systems. Pol. J. Environ. Stud. 24, (1), 285, 2015.

3. DE VRIES F.T., SHADE A. Controls on soil microbial community stability under climate change. Front. Microbiol. 4, 1, 2013.

4. TORSVIK V., OVREAS L., THINGSTAD T.F. Prokaryotic diversity - magnitude, dynamics and controlling factors. Science 296, 1064, 2002.

5. TSCHARNTKE T., CLOUGH Y., WANGER T.C., JACKSON L., MOTZKE I., PERFECTO I., VANDERMEER J., WHITBREAD A. Global food security, biodiversity conservation and the future of agricultural intensification. Biol. Conserv. 151, 53, 2012.

6. CHAPPEL M.J., LA VALLE L.A. food security and biodiversity; can we both? Agric. Hum. Val. 28, 3, 2011.

7. FIERER N., BRADFORD M.A., JACKSON R.R. Toward an ecological classification of soil bacteria. Ecology. 88, 1354, 2007.

8. LANGER U., BÖHME L., BÖHME F. Classification of soil microorganisms based on growth properties: a critical view of some commonly used terms. J. Plant Nutr. Soil Sc. 167, 267, 2004.

9. WOLIŃSKA A., SZAFRANEK-NAKONIECZNA A., BANACH A., REKOSZ-BURLAGA H., GORYLUKSALMONOWICZ A., BŁASZCZYK M., STĘPNIEWSKA Z., GÓRSKI A. Biological degradation of agricultural soils from Lublin region (SE Poland). Int. J. Curr. Microbiol. App. Sci. 3, (11), 558, 2014.

10. FIERER N., LAUBER C.L., RAMIREZ K.S., ZANEVELD J., BRADFORD M.A., KNIGHT R. Comparative metagenomic, phylogenetic and physiological analyses of soil microbial communities across nitrogen gradient. ISME J. $\mathbf{6}$, 1007, 2012.

11. CAMPBELL J.H., ZAK J.C., JETER R.M., STRAUSS R.E. Environmental effects on distributions of culturable soil oligotrophic bacteria along an elevational gradient in the Chihuahuan desert. J. Arid Environ. 99, 41, 2013.

12. WOLIŃSKA A., BENNICELLI R.P. Dehydrogenase activity response to soil reoxidation process described as varied conditions of water potential, air porosity and oxygen availability. Pol. J. Environ. Stud. 19, (3), 651, 2010.

13. WOLIŃSKA A., STĘPNIEWSKA Z., SZYMAŃSKA E. Dehydrogenase activity of soil microorganisms and total
DNA level in soil of different use. J. Agric. Sci. Tech. B. 3, 613, 2013.

14. MARTINEZ-SELGADO M.M. GUTIERREZ-ROMERO V., JANNSENS M., ORTEGA-BLU R. Biological soil quality indicators: a review. Formatex Research Centre, Badajoz, pp. 319-328, 2010.

15. JIA G.M., ZHANG P.D., WANG G., CAO J., HANG J.C., HUANG Y.P. Relationship between microbial community and soil properties during natural succession of abandoned agricultural land. Pedosphere. 20, (3), 352, 2010.

16. GLIŃSKI J., OSTROWSKI J., STĘPNIEWSKA Z., STĘPNIEWSKI W. Soil samples bank representing mineral soils of Poland. Prob. Agrophys. 66, 5, 1991 [In Polish].

17. BIEGANOWSKI A., WITKOWSKA-WALCZAK B., GLIŃSKI J., SOKOŁOWSKA Z., SŁAWIŃSKI C., BRZEZIŃSKA M., WŁODARCZYK T. Database of Polish arable mineral soils: a review. Int. Agrophys. 27, 335, 2013.

18. RAYMOND L., KEPNER J.R., PRATT J.R. Use of fluorochroms for direct enumeration of total bacteria in environmental samples: past and present. Microbiol. Rev. 58, (4), 603, 1994.

19. WETZEL R.G., LIKENS G.E. Limnological analyses, $2^{\text {nd }}$ ed., Springer-Verlag, pp. 391-392, 1991.

20. HATTORI R., HATTORI T. Sensitivity to salts and organic compounds of soil bacteria isolated on diluted media. J. Gen. Appl. Microbiol. 26, 1, 1980.

21. JANUŠAUSKAITE D., KADŽIENE G., AUŠKALNIENIE $O$. The effect of tillage system on soil microbiota in relation to soil structure. Pol. J. Environ. Stud. 22, (5), 1387, 2013.

22. WEYMAN-KACZMARKOWA W. Interdependencies between oligotrophic and copiotrophic bacteria in soils of different mechanical structures. Pol. J. Soil Sci., 29, (1), 65, 1996.

23. PAUL E.A., CLARK F.E. Soil Microbiology and Biochemistry. UMCS, Lublin, 2000 [In Polish].

24. WOLNA-MARUWKA A., KLAMA J., NIEWIADOMSKAA. Effect of fertilization using communal sewage sludge on respiration activity and counts of selected microorganisms in the grey brown podzolic soil. Pol. J. Environ. Stud., 16, (6), 899, 2007.

25. WEYMAN-KACZMARKOWA W., PĘDZIWILK Z. The development of fungi as affected by $\mathrm{pH}$ and type of soil, in relation to the occurrence of bacteria and soil fungistatic activity. Microbiol. Res., 155, 107, 2000.

26. BRZEZIŃSKA M., STĘPNIEWSKA Z., STĘPNIEWSKI W. Soil oxygen status and dehydrogenase activity. Soil Biol. Biochem., 30, 1783, 1998.

27. WŁODARCZYK T. Some aspects of dehydrogenase activity in soils. Int. Agrophys., 22, 371, 2000.

28. BŁOŃSKA E. Enzyme activity in forest peat soils. Folia Forest. Pol., 52, 20, 2010.

29. JEZIERSKA-TYS S., RACHOŃ L., RUTKOWSKA A., SZUMIŁO G. Microbial activity in soil under winter wheat. Int. Agrophys., 25, 21, 2011.

30. CLASSENS S., RIEDEL K.J., VAN RENSBURG L., MORGENTHAL T.L., VAN RENSBURG P.J. Soil microbial properties in coal mine tailings under rehabilitation. Appl. Ecol. Environ. Res., 4, (1), 75, 2005. 